Acta Theriologica 36: $(3-4): 369-373,1991$.

PL ISSN $0001-7051$

\title{
Activity pattern of the red fox Vulpes vulpes in Doñana, SW Spain
}

\author{
Jorge SERVIN, Jaime R. RAU* and Miguel DELIBES
}

\begin{abstract}
Servín J., Rau J. R. and Delibes M. 1991. Activity pattern of the red fox Vulpes vulpes in Doñana, SW Spain. Acta theriol. 36: $369-373$.

Radio tracking data from six red foxes Vulpes vulpes (Linnaeus, 1758) in Coto Doñana (SW Spain) were used to obtain the activity pattern throughout the day and night. Results suggested that females travelled longer distances during the night than during the day $(p<0.001)$. Males travelled distances similar during both day and night $(p>0.15)$ but they travelled farther than females throughout $24 \mathrm{~h}$ periods $(p<0.05)$.

Instituto de Ecología, Unidad Durango, Apdo. Postal No. 632, C.P. 34000, Durango, Dgo., México (JS); Estación Biológica de Doñana, CSIC Apdo. 1056, 41013 Sevilla, Spain (MD)

Key words: activity pattern, Vulpes vulpes, Doñana, Spain
\end{abstract}

\section{Introduction}

Studies of travelling distances and daily activity patterns of certain carnivores are difficult, due to their extensive home ranges, secretive behaviour, fast movements and low population densities. However, studies on wild animals through indirect methods try to establish the hours of the day when these species are more active (Kruuk 1972, Schaller 1972, Ables 1975, Alvarez et al. 1983, Andelt 1985, Tester 1987, Schaller et al. 1989).

In certain biotopes, the mammal community expends its activities from a temporal point of view (Valverde 1967). Carnivores present three basic activity patterns: (1) Nocturnal activity; moving and feeding during the night, as foxes and hyenas do (Kruuk 1972, Maurel 1980, 1983; (2) Crepuscular activity, like the coyote and giant panda, when their major movements and activities coincide with sunset and sunrise (Andelt 1985, Schaller et al. 1989); (3) Diurnal activity, like the coati, African wild dog and mongoose, where moving and feeding activities occur only during daytime (Delibes and Beltran 1986, Gittleman 1989). There also exist seasonal variations in activity patterns, in accordance with female breeding periods (Andelt and Gipson 1979).

Preliminary results of the red fox Vulpes vulpes (Linnaeus, 1758) activity patterns from Doñana National Park, Spain, are reported in this paper. Travelling distances in cycles of 24 hours are also given.

\footnotetext{
* Present address: Instituto Profesional de Osorno, Dept. Ciencias Exactas \& Naturales, Casilla 933, Osorno, Chile
} 


\section{Study area and methods}

This research was conducted at the Doñana National Park, in a Mediterranean shrub area, where a variety of dominant plants exists, for example: Halimium halimifolium, H. conmutatum, Cistus libanotis, Erica scoparia and Calluna vulgaris, among others (Allier et al. 1974). The weatherin this zone is Mediterranean-Atlantic with hot and dry summers, while winters are wet and cold (Allier et al. 1974, Delibes 1980). The fox movements were on the shrub area and on an ecotone between a floodable area or marisma and a wet zone of rush and grassland of Cynodon sp. and Paspalum sp.

Foxes were captured with snares, steel foothold traps (No. 2) and two door box traps similar to the Tomahawk type. Steel foothold traps were covered with soft material to avoid injuries when an animal was caught. Traps were baited with synthetic urine (Cronck Co.), and a mix of chicken with fish was also used.

Two females and four males were captured and anesthetised with a mixture of ketamine and xylazine (Delibes and Beltran 1986). Foxes were weighed and radiocollars (Biotrack) of the frequency $150-152 \mathrm{MHz}$ were attached. Males were radio-tracked from November 1984 to February 1985; and females from February to June 1985 (Table 1).

Table 1. Radiotracking time, intensive $24 \mathrm{~h}$ periods, and number of locations of six red foxes in Doñana National Park, SW Spain.

\begin{tabular}{lcccccc}
\hline $\begin{array}{l}\text { Fox } \\
\text { Number }\end{array}$ & Sex & $\begin{array}{c}\text { Weight } \\
(\mathrm{kg})\end{array}$ & $\begin{array}{c}\text { Date of } \\
\text { capture }\end{array}$ & $\begin{array}{c}\text { Total days } \\
\text { monitored }\end{array}$ & $\begin{array}{c}\text { Tracking } \\
24 \mathrm{~h}\end{array}$ & $\begin{array}{c}\text { Number of } \\
\text { locations }\end{array}$ \\
\hline 210 & M & 6.0 & Nov. 84 & 7.3 & 1 & 59 \\
213 & M & 4.5 & Dec. 84 & 72 & 2 & 91 \\
284 & M & 5.9 & Dec. 84 & 84 & 3 & 97 \\
$211^{*}$ & M & 6.5 & Jan. 85 & 31 & 2 & 44 \\
$112^{* *}$ & F & 6.0 & Jan. 85 & 159 & 8 & 225 \\
214 & F & 5.1 & Feb. 85 & 142 & 6 & 250 \\
\hline
\end{tabular}

* Dead on February 18th, 1985. ** Breeding female with pups (spring 1985).

Table 2. Mean distances $(\mathrm{km})$ travelled by red foxes during day and night in Doñana National Park.

\begin{tabular}{lcccc}
\hline & Day & Night & $24 \mathrm{~h}$ & $\mathrm{~N}$ \\
\hline Females & 1.35 & 4.58 & 5.93 & 14 \\
Males & 4.45 & 5.37 & 9.82 & 8 \\
Average & 2.90 & 4.97 & 7.88 & 22 \\
\hline
\end{tabular}

Radio locations of foxes were determined by compass bearings from 2 of 75 tracking stations. An "all terrain" vehicle was necessary in order to move faster from one station to the other, and thus enabled the triangulation method to be used (Mech 1983). Radio signals were monitored with a receiver model LA-12 (AVM Instrument Co.), connected to a portable three element "yagi" antenna. For visual recognition of the animal, each collar was covered with a reflective plastic of different colors.

We assumed the distance travelled per hour was a measurement of activity, due to the fact that Canids are considered cursorial pursuers of prey. Hence we obtained distances travelled in a straight line between locations as an index of activity. 
From 766 radiofixes accumulated during intensive $24 \mathrm{~h}$ radiotracking periods with a one-hour interval, a $\pm 5^{\circ}$ error was calculated from the bearing lectures (Table 1). The diurnal period is considered from 18:01 to 06:00 h, while the nocturnal period is from $06: 01$ to $18: 00 \mathrm{~h}$, and the crepuscular time considered from 05:45 to $06: 45 \mathrm{~h}$ (sunrise) and 17:45 to 18:45 h (sunset). Paired comparisons were made using the Student $t$-test in order to determine activity relationships between males and females, and also travelling distances during night and day. The $p<0.05$ calculation was required for the statistical significance (Sokal and Rohlf 1981).

\section{Results and discussion}

The fox mean home range size was 116 ha, like in studies by Macdonald (1977), Maurel (1980), Boitani et al. (1984) and Blanco (1986). Foxes usually visit all boundary areas of their home range, and usually the pattern of movement is done in a rather erratic way.

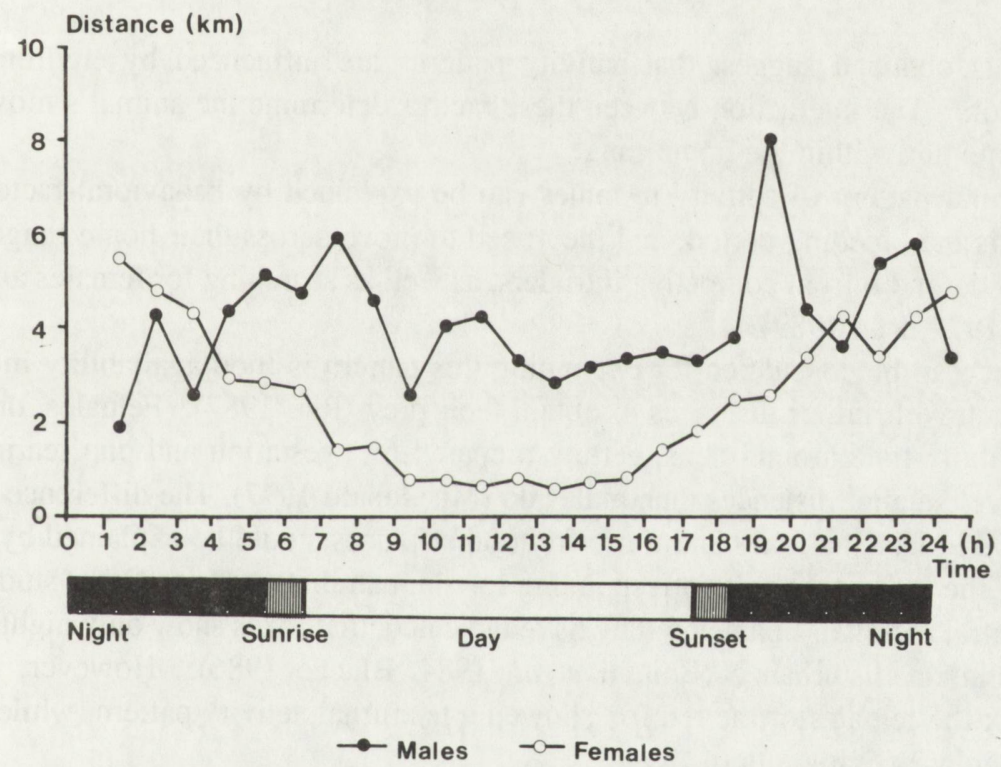

Fig. 1. Activity pattern of red fox (Vulpes vulpes) in Doñana, SW Spain; (○) females; ( ) males.

The female fox activity had its maximum mean of distance travelled of $0.55 \mathrm{~km}$, between 00:00 and 01:00 hours; while minimum travelling distance of $0.05 \mathrm{~km}$ during daytime was between 12:00 and 13:00 hours (Fig. 1). Throughout all the nocturnal periods from 18:00 to 06:00 hours, females travelled, within their home range, a mean distance of $4.58 \mathrm{~km}$, while during daytime, a mean distance of $1.35 \mathrm{~km}$ was travelled. Therefore, during the study time period females showed a nocturnal activity and were more active at night than on daytime $(t=7.78 ;$ d.f. $=23 ; p<0.001)$. The total mean of travelling distances of vixens was $5.93 \mathrm{~km}$ in the 24 hour cycles (Table 2).

Male foxes displayed both night and day activity, having maximum mean travelling distances during sunset between 18:00 and 19:00 hours $(\bar{x}=0.81 \mathrm{~km} ; \mathrm{n}=7)$ and sunrise from 
06:00 to $07: 00$ hours $(\bar{x}=0.59 \mathrm{~km} ; \mathrm{n}=5)$. They showed a crepuscular activity rhythm. At night foxes moved $5.37 \mathrm{~km}$, slightly more than during the daytime figure of $4.45 \mathrm{~km}$. However, there were no significant differences between daytime and night movements $(t=1.42$; d.f. $=23 ; p>0.15)($ Table 2$)$.

Comparing distances travelled by males and females in 24 hours, we found that male foxes had a mean travelling distance of $9.82 \mathrm{~km}$, and female foxes $5.93 \mathrm{~km}$, the difference being significant $(t=2.29$; d.f. $=21 ; p<0.05)$ (Table 2).

Total mean travelling distances for the red fox in Doñana National Park was $7.87 \mathrm{~km}$ in 24 hour cycles $(n=22)$. The daytime mean distance covered was $2.90 \mathrm{~km}$, while in the night foxes moved $4.97 \mathrm{~km}$, suggesting that nocturnal movements were larger than diurnal ones $(t=85.89 ;$ d.f. $=23 ; p<0.001)$.

\section{Conclusions}

The results obtained suggest that activity patterns are influenced by enviromental and endogen factors. The interaction between these factors determine the animal's movements in relation to time and within the home range.

The irregular pattern of activity in males can be explained by behavioral factors. In late winter there is the breeding period, and they need to move across their home range for scent marking, and defend it from competing intruders, as well as searching for females and for food (Macdonald 1977, Rau 1987).

Other aspect to be considered for explaining this pattern is food availability in winter, as foxes need to travel further distances to obtain their prey (Rau 1987). Females, on the other hand, spend more time around dens, getting prepared for gestation and pup rearing. This is why they travel smaller distances than males do (Macdonald 1977). The difference of activity patterns found in Doñana foxes and those from other places, could be explained by the actual protection of the study area and corresponding low human disturbance. Other studies carried out in the central region of Spain and Italy have indicated, that foxes show only nightly activity, because of human disturbance (Boitani et al. 1984, Blanco 1986). However, in Doñana National Park the females of the red fox showed a nocturnal activity pattern, while the males had a crepuscular activity pattern.

There is the need to continue our studies on adult foxes in order to determine the differences between males and females in daily and seasonal activity patterns in areas of varying human intervention.

Acknowledgements: We wish to thank Mr. R. Laffitte and J. F. Beltran for their helpful labor during field work. This research was funded by CSIC, Biological Station of Doñana, Spain. Instituto de Ecología A.C., México. Dept. Ciencias Exactas, Inst. Profesional de Osorno, Chile. Two grants supported J. Servín and J. Rau from Instituto de Cooperación Iberoamericana. To M. Vences, A. Catalán and I. Mateos, for their encouragement. Two anonymous referees read and improved the manuscript. M. Huxley and L. Johnson helped in the English translation.

\section{References}

Ables E. D. 1975. Ecology of the red fox in North America. [In: The Wild Canids; their systematics, behavioral ecology and evolution. M. W. Fox, ed.]. Van Nostrand Reinhold, Amsterdam: 216 - 236. 
Allier C., Gonzalez Bernaldez F. and Ramirez Diaz L. 1974. Mapa Ecológico de la Reserva Biológica de Doñana. División de Ciencias del C.S.I.C., Estación Biológica de Doñana, Sevilla.

Alvarez F., Azcarate T., Aguilera E. and Martin-Franquelo R. 1983. Circadian activity rhythms in a vertebrate community of Doñana. Act. Congr. Int. Fauna Cineg. Silvestre. 15: $379-387$.

Andelt W. F. 1985. Behaviour ecology of coyotes in south Texas. Wildl. Monogr. 49: $1-45$.

Andelt W. F. and Gipson P. S. 1979. Home range, activity, and daily movements of coyotes. J. Wildl. Manage. 43: $944-951$.

Blanco J. C. 1986. On the diet, size and use of home range and activity patterns of a red fox in central Spain. Acta theriol. 31: $547-556$.

Boitani L., Barraso P. and Grimod I. 1984. Ranging behaviour of the red fox in the Gran Paradiso National Park (Italy). Boll. Zool. 51: 275 - 284.

Delibes M. 1980. El lince Ibérico, ecología y comportamiento alimenticios en el Coto Doñana, Huelva. Doñana, Acta Vertebrata 7 (esp.): 1 - 128.

Delibes M. and Beltran J. F. 1985. Activity, daily movements and home range of an Ichneumon or Egyptian Mongoose (Herpestes ichneumon) in southern Spain. J. Zool., Lond. 207: 610 - 613.

Gittleman J. L. 1989. Carnivore group living: comparative trends. [In: Carnivore behaviour, ecology, and evolution. J. L. Gittleman, ed.]. Cornell University Press, New York: $183-207$.

Kruuk H. 1972. The spotted hyena. University of Chicago Press, Chicago: $1-335$.

Maurel D. 1980. Home range and activity rhythm of adult male foxes during the breeding season. [In: A handbook on biotelemetry and radiotracking. C. J. Amlaner, Jr. and D. W. Macdonald, eds]. Pergamon Press, Oxford: $697-702$.

Maurel D. 1983. Movements and space utilization in the fox (Vulpes vulpes) as studied by radio-tracking in the forest of Chizé. Act. Cong. Int. Fauna Cineg. Silvestre 15: $421-433$.

Macdonald D. W. 1977. The behavioral ecology of the red fox. [In: Rabies the facts. C. Kaplan, ed.]. Oxford University Press, Oxford: 70 - 90.

Mech L. D. 1983. Handbook of animal radio-tracking. University of Minnesota Press, Minneapolis: 1 - 107.

Rau R. J. 1987. Ecología del zorro, Vulpes vulpes (L.), en la Reserva Biológica de Doñana, S.O. de España. Tesis Doctoral. Univ. de Sevilla, España: $1-258$.

Schaller G. 1972. The Serengeti lion. Chicago Univ. Press, Chicago: $1-480$.

Schaller G., Jinchu H., Wenshi P. and Jing Z. 1989. The giant pandas of Wolong. Chicago Univ. Press, Chicago: 1-298.

Sokal R. R. and Rohlf. F. J. 1969. Biometry. W.H. Freeman and Co., San Francisco, Calif.: $1-253$.

Tester J. R. 1987. Changes in daily activity rhythms of some free-ranging animals in Minnesota. Can. Field Nat. 101: $13-21$.

Valverde J. A. 1967. Estructura de una comunidad de vertebrados terrestres. Monogr. Est. Biol. Doñana, 1: 1-219.

Received 19 October 1990, accepted 30 September 1991. 